\title{
SEM, EDS and Electrical Capacitance Study on Electrodeposited Ni-Cu Layers
}

\author{
OANA CLAUDIA CIOBOTEA BARBU ${ }^{1,2}$, IOANA ALINA CIOBOTARU ${ }^{1}$, ANCA COJ OCARU' ${ }^{1}$, FLORIN MIHAI BENGA', \\ DANUT IONEL VAIREANU1,* \\ 'University Politehnica of Bucharest, Faculty of Applied Chemistry and Materials Science, 1-7 Polizu Street, 011061, Bucharest, \\ Romania \\ ${ }^{2}$ Geological Institute of Romania, 1 Caransebes Str., 01227, Bucharest, Romania

\begin{abstract}
Nickel-Copper metallic layers were deposited onto a steel substrate by using the electrochemical method. The morphology and the chemical composition of the deposited layers were studied by scanning electron microscopy. The electrical capacitance was measured on a functional supercapacitor made of two Ni-Cu deposited layers and a Nafion 117® membrane hydrated with distilled water, which served as a dielectric separator.
\end{abstract}

Keywords: electrodeposited Ni-Cu; SEM; EDS; supercapacitor; capacitance; temperature

Supercapacitors are devices used for energy storage and release at demand intended to replace the conventional batteries [1-5]. The research in energy storage field is focused on improving the existing energy devices in terms of storage capacity, easy charging and extended lifetime [6].

Electrodeposition is a technique used to obtain materials with controlled structure and particular properties suitable to be used in the supercapacitors manufacture $[7,8]$.

Several studies have been carried out to investigate the electrochemical behaviour of $\mathrm{Ni}$-Cu alloys in acidic, neutral or slightly alkaline solutions, but few have been reported on this subject [9-11].

The high interest shown in the study of Ni-Cu alloys is related to their corrosion resistance, mechanical and magnetic properties, and optical properties. This type of alloy can be used to make optical mirrors due to its high reflection and gloss [12-14]. In addition to these properties, (such as: electrical and thermal conductivity, ductility and malleability are added [13-16].

The Ni-Cu electrochemical deposition process is carried out in two steps. In the first stage, a dendritic Ni-Cu deposition is formed by applying a controlled current density, and hydrogen bubbles are generated at the surface of the electrode. During Ni-Cu electrochemical deposition the hydrogen bubbles disrupt the continuous growth of metal layer generating dendritic morphologies. In the second stage, the production of the pores in the $\mathrm{Ni}$-Cu layer occurs due to the selective $\mathrm{Cu}$ dealloying from the $\mathrm{Ni}-\mathrm{Cu}$ dendritic structure. The convection created by detachment of hydrogen bubbles leads to the reduction of the diffusion layer from the surface of the electrode $[4,17]$.

The aim of this paper is to characterize some $\mathrm{Ni}-\mathrm{Cu}$ deposits on steel substrates obtained at different deposition parameters that may be used as supercapacitor components.

\section{Experimental part}

Materials and methods

A steel plate of $1.6 \mathrm{~cm}^{2}$ was used as metallic substrate for the deposition. The plates were mechanically polished with emery paper, rinsed with water and ethanol. They are electrically isolated on one side, so that the layer deposition takes place only on one side of the steel plate.
The electrochemical deposition cell contained a platinum mesh as anode (active surface area $5 \mathrm{~cm}^{2}$ ), the steel plate as a cathode, the electrolyte solution containing $\mathrm{NiSO} \cdot 7 \mathrm{H}_{2} \mathrm{O}, \mathrm{CuSO} \cdot 5 \mathrm{H}_{2} \mathrm{O}, \mathrm{H}_{2} \mathrm{SO}_{4}, \mathrm{HCl}$ (Sigma-Aldrich, ChimReactiv) similar to that reported in [11]. The electrochemical installation is made of the cell, a variable resistance, a power source, an ammeter and a thermostatic water bath to maintain the temperature at constant values.

The $\mathrm{Ni}-\mathrm{Cu}$ depositions working parameters: a). temperatures namely $30^{\circ} \mathrm{C}$ and $40^{\circ} \mathrm{C}$, b). current densities namely $\left.0.7 \mathrm{~A} / \mathrm{cm}^{2}, 1.1 \mathrm{~A} / \mathrm{cm}^{2}, 1.5 \mathrm{~A} / \mathrm{cm}^{2}, \mathrm{c}\right)$. deposition times of $50 \mathrm{~s}, 100 \mathrm{~s}, 150 \mathrm{~s}$.

\section{Methods of investigation}

The morphological and compositional properties of the $\mathrm{Ni}$-Cu deposited layers were studied by Scanning Electron Microscopy (SEM, Zeiss Merlin Gemini II) and Dispersive Energy Spectrometry (using SEM, OXFORD Instrument with X-Max 50 detector).

The electrical capacity performance was assessed by constructing a symmetrical capacitor supercapacitor made of two steel plates covered at identical parameters, with Ni-Cu layers containing an activated Nafion $117 \AA$ membrane as a dielectric separator. The membrane was used in hydrated state in distilled water. The measurements were made with a dedicated professional LCR-Multimeter 4095 (Germany), the system configuration is similar as in [18].

\section{Results and discussions \\ Morphology}

An alloy of $\mathrm{Fe}, \mathrm{C}$ and $\mathrm{O}$ having a dendritic structure of $\mathrm{Ni}$ Cu deposits was used as the substrate.

Figure $1 \mathrm{~A}$ show the SEM images of $\mathrm{Ni}-\mathrm{Cu}$ layers, deposited at a current density of $1.5 \mathrm{~A} / \mathrm{cm}^{2}$ for $150 \mathrm{~s}$, at a temperature of $30^{\circ} \mathrm{C}$. One may see that the deposit is porous, cracked and very thick with the dendritic shape of the crystals same as the deposition obtain at 100s (B). As seen at the samples deposited at a high current and high density, the layer deposited is a thin film on the surface of the crystals formed by the hydrogen bubble convection process. The pore diameters are approximately $10 \mu \mathrm{m}$ and the connecting bridges thickness is approximately $18 \mu \mathrm{m}$ for the deposition at $150 \mathrm{~s}$ and for $100 \mathrm{~s}$ pore diameter is 

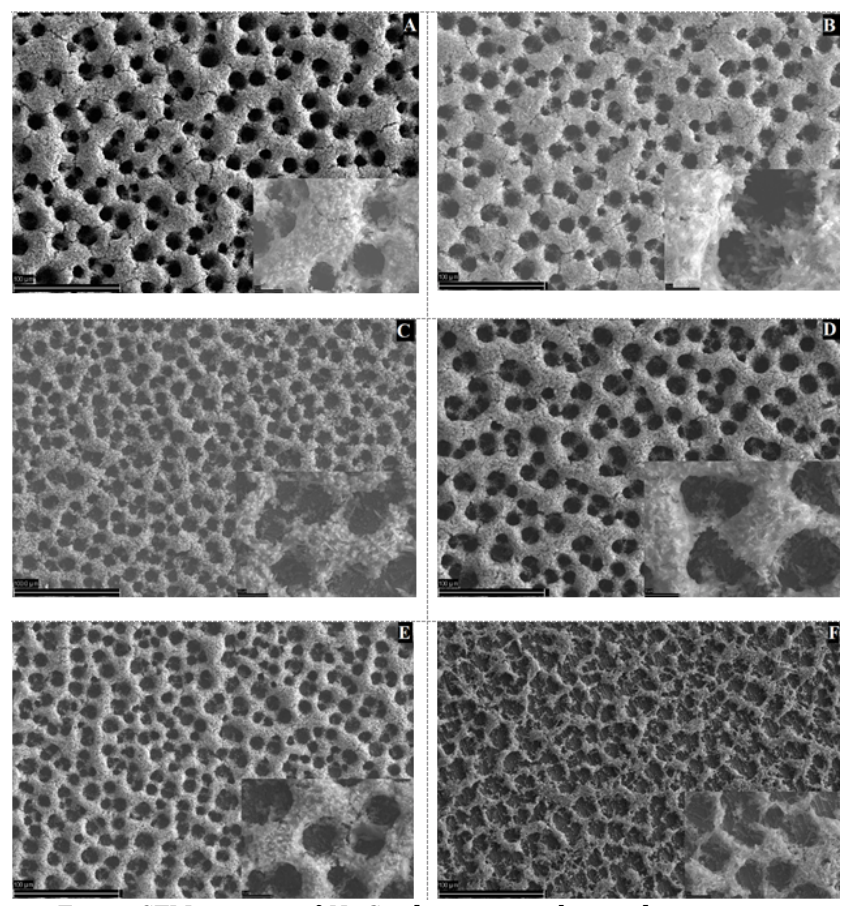

Fig. 1. SEM images of Ni-Cu deposition obtained at a current density of $1.5 \mathrm{~A} / \mathrm{cm}^{2}$, for $150 \mathrm{~s}(\mathrm{~A}), 100 \mathrm{~s}(\mathrm{~B})$ and $50 \mathrm{~s}(\mathrm{C})$, and a current density of $0.7 \mathrm{~A} / \mathrm{cm}^{2}$ for $150 \mathrm{~s}(\mathrm{D}), 100 \mathrm{~s}(\mathrm{E})$ and $50 \mathrm{~s}(\mathrm{~F})$ at a temperature of $30^{\circ} \mathrm{C}$

about $11 \mu \mathrm{m}$ and the connecting bridges thickness is about $14 \mu \mathrm{m}$. For the same current density but a deposition time of $50 \mathrm{~s}(\mathrm{C})$, the deposition is one with defined butthin pores, that the steel substrate is visible between the bonding bridges. The pore diameter is about $10 \mu \mathrm{m}$ and the connecting bridges thickness is about $9 \mu \mathrm{m}$.

At a deposition current density of $0.7 \mathrm{~A} / \mathrm{cm}^{2}$ for $150 \mathrm{~s}$ (D) the Ni-Cu layer is very thick and porous. The pore diameter is approximately $14 \mu \mathrm{m}$, while the bond bridge thickness is about $14 \mu \mathrm{m}$. If the deposition time decreases at $100 \mathrm{~s}$ (E) the pore diameter drops down to approximately $9 \mu \mathrm{m}$ and the thickness of the connecting bridges is to $7 \mu \mathrm{m}$. The deposition performed at $50 \mathrm{~s}(\mathrm{~F})$ and at current density of $0.7 \mathrm{~A} / \mathrm{cm}^{2}$ is very thin, the steel substrate can be easily seen, but still have a dendritic shape of crystals. The pore diameter is about $14 \mu \mathrm{m}$ and the connecting bridges thickness is about 7um.

Figure 2 A2 shows the SEM images of $\mathrm{Ni}$ - $\mathrm{Cu}$ layers, deposited at a current density of $1.5 \mathrm{~A} / \mathrm{cm}^{2}$ for $150 \mathrm{~s}$, at a temperature of $40^{\circ} \mathrm{C}$. One may see that the deposit is porous, cracked and very thick with the dendritic shape of the crystals same as the deposition obtain at 100s (B2). The pore diameter is approximately $15 \mu \mathrm{m}$ and the connecting bridges thickness is approximately 16im for the deposition at $150 \mathrm{~s}$ and for $100 \mathrm{~s}$, the pore diameter is about 13im and the connecting bridges thickness is about $21 \mu \mathrm{m}$.

For the same current density but a deposition time of 50 $\mathrm{s}(\mathrm{C} 2)$, the deposition is one with defined but thin pores, that the steel substrate is visible between the bonding bridges. The pore diameter is about $13 \mu \mathrm{m}$ and the connecting bridges thickness is about $18 \mu \mathrm{m}$. Ata deposition current density of $0.7 \mathrm{~A} / \mathrm{cm}^{2}$ for $150 \mathrm{~s}$ (D2) the Ni-Cu layer is thick and porous. The pore diameter is approximately $19 \mu \mathrm{m}$, while the bond bridge thickness is about $15 \mu \mathrm{m}$.

If the deposition time decreases at $100 \mathrm{~s}(\mathrm{E} 2)$ the pore diameter drops down to approximately $17 \mu \mathrm{m}$ and the thickness of the connecting bridges is to $13 \mu \mathrm{m}$. The deposition performed at 50 s (F2) and a current density of $0.7 \mathrm{~A} / \mathrm{cm}^{2}$ is very thin, the steel substrate can be easily seen,
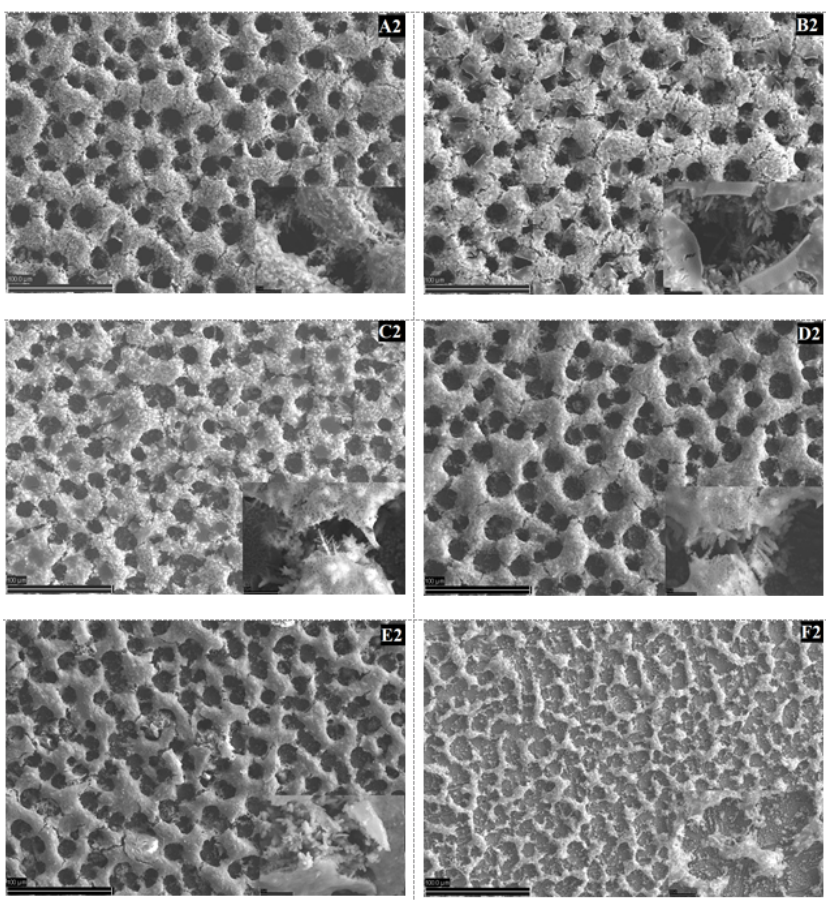

Fig. 2. SEM images of Ni-Cu deposition obtained at a current

density of $1.5 \mathrm{~A} / \mathrm{cm}^{2}$, for $150 \mathrm{~s}$ (A2), 100s (B2) and $50 \mathrm{~s}$ (C2), and a current density of $0.7 \mathrm{~A} / \mathrm{cm}^{2}$ for $150 \mathrm{~s}$ (D2), $100 \mathrm{~s}$ (E2) and $50 \mathrm{~s}$ (F2) at a temperature of $40^{\circ} \mathrm{C}$

but still have a dendritic shape of crystals. The pore diameter is about $13 \mu \mathrm{m}$ and the connecting bridges thickness is about $8 \mu \mathrm{m}$.

\section{Composition}

The nickel concentration increases as the deposition time and current density decreases. At a deposition time of $50 \mathrm{~s}$, a current density of $0.7 \mathrm{~A} / \mathrm{cm}^{2}$ and a deposition temperature of $30^{\circ} \mathrm{C}$, the Ni concentration is $16.13 \%$ and that of $\mathrm{Cu}$ is $57.7 \%$ while at a deposition time of $150 \mathrm{~s}$ and a current density of $1.5 / \mathrm{cm}^{2}$, Ni concentration is $8.35 \%$ and $\mathrm{Cu}$ is $42.72 \%$.

At a current density of $1.1 \mathrm{~A} / \mathrm{cm}^{2}$ regardless of the time of deposition, the Ni concentration is the highest. At a deposition time of $150 \mathrm{~s}$, the Ni concentration is $15.94 \%$, at $100 \mathrm{~s}$, is $17.39 \%$ and at $50 \mathrm{~s}$, is $30 \%$.

At a deposition temperature of $40^{\circ} \mathrm{C}$, the Ni concentration has the highest values at a deposition of $100 \mathrm{~s}$ and a current density of $1.5 \mathrm{~A} / \mathrm{cm}^{2}$, it does not exceed $22.69 \%$ and the Cu concentration is $34.71 \%$.

The lowest Ni concentration, $6.9 \%$, is recorded for a deposition at a current density of $1.1 \mathrm{~A} / \mathrm{cm}^{2}$ for $150 \mathrm{~s}$ and the equivalent Cu concentration is $45.4 \%$.

\section{Electrical capacitance measurements}

In figure 3 is shown that the values of the electrical capacitance varies between $16.9 \mu \mathrm{F} / \mathrm{cm}^{2}$ at a deposition temperature of $30^{\circ} \mathrm{C}$ and $16.4 \mu \mathrm{F} / \mathrm{cm}^{2}$ at a deposition temperature of $40^{\circ} \mathrm{C}$ for a current density of $0.7 \mathrm{~A} / \mathrm{cm}^{2}$ and 50 s deposition time. If the time deposition increases up to $150 \mathrm{~s}$, the electrical capacitance varies between $8.8 \mu \mathrm{F} /$ $\mathrm{cm}^{2}$ at a deposition temperature of $30^{\circ} \mathrm{C}$ and $17.9 \mu \mathrm{F} / \mathrm{cm}^{2}$ at a deposition temperature of $40^{\circ} \mathrm{C}$.

If the deposition current density increases at $1.5 \mathrm{~A} / \mathrm{cm}^{2}$, the electrical capacitance at a deposition time of $50 \mathrm{~s}$ increases up to $35.8 \mu \mathrm{F} / \mathrm{cm}^{2}$ at a deposition temperature of $30^{\circ} \mathrm{C}$ and decreases to $9.3 \mu \mathrm{F} / \mathrm{cm}^{2}$ when the deposition temperature is $40^{\circ} \mathrm{C}$. If the time deposition increases up to $150 \mathrm{~s}$, the electrical capacitance varies between $42.9 \mu \mathrm{F} /$ 

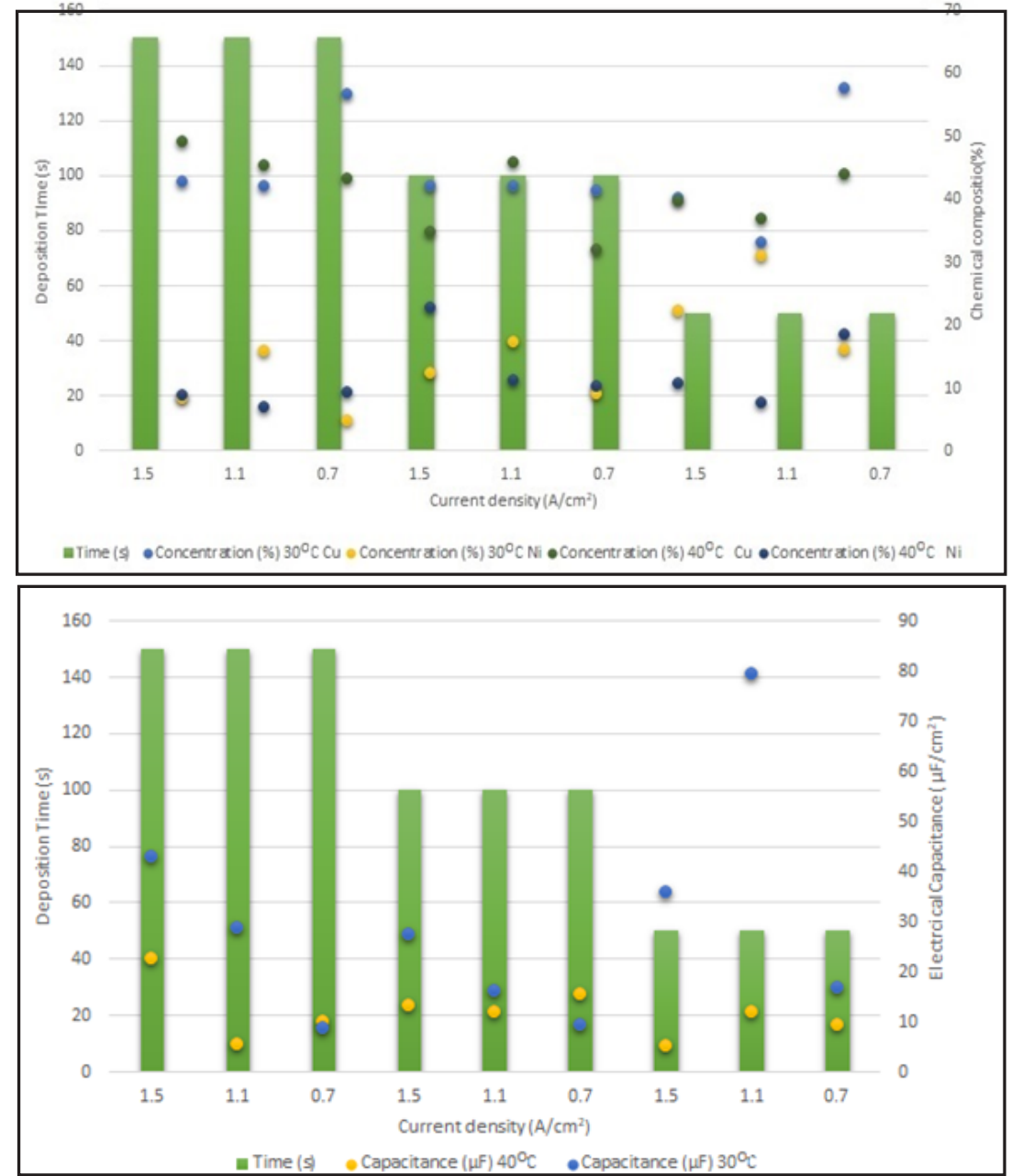

Fig. 3. The Ni-Cu composition in the deposited layers
Fig. 4. The variation of the capacitance depending on temperature, time and current density $\mathrm{cm}^{2}$ at a deposition temperature of $30^{\circ} \mathrm{C}$ and $40.4 \mu \mathrm{F} / \mathrm{cm}^{2}$ at a deposition temperature of $40^{\circ} \mathrm{C}$.

The highest value of electrical capacitance, $79.4 \mu \mathrm{F} / \mathrm{cm}^{2}$, is measured at a deposition performed at a current density of $1.1 \mathrm{~A} / \mathrm{cm}^{2}$ at $50 \mathrm{~s}$ deposition time and $30^{\circ} \mathrm{C}$ deposition temperature.

\section{Conclusions}

Electrodeposition of Ni-Cu alloys carried out in acidic electrolyte solutions was used to obtain a nanostructured metallic foam in order to be used as electrode plates for supercapacitors. The Ni-Cu deposits on steel plates have randomly distributed circular pores with dendritic crystal structure. The parameters applied to the deposition stage, have a strong influence on the thickness, morphology of the final deposits, affecting also the pore diameters and the connecting bridges and the Ni-Cu ratio.

Acknowledgements: Special thanks go to Mr. Corneliu Andrei for providing the logistic support. Miss Oana Claudia Ciobotea-Barbu and Mr. Florin-Mihai Benga are financially supported by the Ministry of National Education of Romania doctoral grants. The SEM and EDS analysis were performed at MICROCOSMOS Laboratory from Geological Institute of Romania.

\section{References}

1. LOKHANDE, C.D., DUBAL, D.P., O.H-J00, Curr. Appl. Phys. 11, 2011, p. 255-270.

2. DEVIVIER, C., TAGLIAFERRI, V., FROVALUSCI, F., UCCIARDELLO, N., Mater. Des, 85, 2015, p. 272-278;

3. MIRZAEIANA, M., OGWUA, A.A., JIRANDEHIB, H.F., AIDAROVAC, S., OSPANOVAD, Z., TSENDZUGHULA, N., Coll. S. A: Physicochem. Eng. Aspects, 519, 2017, p. 223-230.
4. EUGENIO, S., SILVA, T.M., CARMEZIM, M.J., DUARTE, R.G., MONTEMOR, M.F., J. Appl. Electrochem., 44, 2014, p. 455-465.

5. MEHER, S. K., JUSTIN, P., RAO, G. R., Nanoscale, 3, 2011, p. 683-692. 6. WU, N., LOW, J., LIU, T., YU, J., CAO, S., Appl. Surf. Sci., 413, 2017, p. 35-40.

7. LANGE, G.A., EUGENIO, S., DUARTE, R.G., SILVA, T.M., CARMEZIM, M.J. MONTEMOR, M.F., J. Electroanal. Chem. 73, 2015, p. 85-92. 8. PELLICER, E., VAREA, A., PANE, S., SIVARAMAN, K.M., NELSON, B.J., SURINACH, S., BARO, M.D., SORT, J., Surf. Coat. Technol., 205, 2011, p. 5285-5293.

9. ISMAIL, K., FATHI, A. W., BADAWY, J Appl. Electrochem., 34, no. 8, 2004, p. 823-831.

10. CIOBOtEA-BARBU, O. C., CIOBOTARU, I. A., BENGA, F. M., VAIREANU, D. I., Rev. Chim. (Bucharest), 70, no. 1, 2019, p. 45 11. CIOBOtEA-BARBU, O. C., CIOBOTARU, I. A., BENGA, F. M., VAIREANU, D. I., Rev. Chim. (Bucharest), 70, no.7, 2019, p. 2335

12. WANG, G., ZHANG, L., ZHANG, J., Chem. Soc. Rev., 41, no. 2, 2012 p. $797-828$.

13. GORANOVA, D., AVDEEV, G., RASHKOV, R., Surf. Coat. Technol., 240, 2014, p. 204-210.

14. BANTHIA, S., SENGUPTA, S., MALLIK, M., DAS, S., DASA, K., Surf. Eng., 33, 2017, p. 1743-2944.

15. TAPPAN, B.C., STEINER, S.A., LUTHER E.P., Angew Chem Int Ed., 49, no. 27, 2010, p. 4544-4565.

16. CHOI, B. N., CHUN, W. W., QIAN, A., LEE, S. J. CHUNG, C.H., Nanoscale, 7, 2015, p. 18561.

17. CHEREVKO, S., KULYK, N., CHUG, C. H., Nanoscale, 4, 2012, p. 568-575.

18. CIOBOTARU, I.A., VAIREANU, D.V., CIOBOTARU, I.E., CIOBOTEABARBU, 0.C., Rev. Chim. (Bucharest), 68, no. 7, 2017, p. 1413-1418.

Manuscript received: 25.07 .2018 